\title{
How Cause Related Marketing Influence Customer Value in Banking Industry?
}

\author{
Hong-Sheng Chang \\ De-Lin Institute of Technology \\ E-Mail: hschang@dlit.edu.tw \\ Tser-Yieth Chen \\ National Taipei University \\ E-Mail: chenty@mail.ntpu.edu.tw \\ Chien-Ming Tseng \\ Ming-Chuan University \\ Central Taiwan University of Science and Technology \\ E-Mail: bryan@ctust.edu.tw
}

\begin{abstract}
This study elucidates how cause related marketing, service quality and perceived risk are related, and explores the influence of service quality and perceived risk on customer value. Service quality found to be affected positively by cause related marketing, whereas cause related marketing negatively influences perceived risks. Finally, exactly how customer value is affected by the service quality and perceived risk is considered, and cause related marketing notably indirectly affect customer value through service quality and perceived risk.
\end{abstract}

Keywords: Cause Related Marketing, Service Quality, Perceived Risk, Customer Value

\section{INTRODUCTION}

Since the last decade, companies are under mounting pressure to take responsibility for the effects of their corporate conduct on society, especially when these effects go beyond the firm's direct commercial interests (Macleod, 2001; Mohr et al., 2001). As a result, an increasing number of companies, small and big alike, has 
developed corporate social responsibility (CSR) programs (Maignan and Ralston, 2002). As a type of CSR, cause-related marketing (CRM) has received particular corporate interest. This is due to the fact that especially CRM might have positive effects on consumer behavior (Sen and Bhattacharya, 2001). This work tries to examine the effect of cause related marketing on service quality, perceived risk and customer value in Taiwan's banking industry. Athanassopoulos (2000) identified customer value as functions of consumers' service quality perceptions. Contrastively, Day and Crask (2000) and Huber and Herrmann (2000) propose that perceived risks associated with service should be included in the assessment of customer value. No study has yet identified the internal relationship among the dimensions of service quality, perceived risk and customer value. Accordingly, the structural relationship among banking service quality, perceived risk and customer value in Taiwanese is explored in this study.

Cause related marketing has become increasingly popular, academic few researchers have begun to examine how consumers respond to it. How consumers think and feel about cause-related marketing is explored by survey method. A framework of consumer responses that includes service quality, perceived risk and perceived value of consumers. Cause related marketing campaigns provide an excellent context for delving into consumers' interpretation of promotions with a social dimension and exploring their behavioral responses to such corporate "do-gooding." Cause related marketing's prevalence and history in the marketplace and its acceptance by both for-profit and nonprofit practitioners (Barnes and Fitzgibbons, 1992), as well as by consumers (Ross Patterson and Stutts, 1992).

Presumably, the success of CRM campaigns reflects, at least in part, the favor ability of consumer responses to a company's support of a cause, culminating in the choice of that company's products or services. Given the complexity and uncertainty associated with the evaluation of CRM campaigns, research is needed that provides insight into whether and when corporate sponsorship of social causes enhances brand choice. However, academic researchers are only beginning to explore consumers' interpretations of and responses to CRM offers (Drumwright 1996). Drumwright (1996) delve into consumers' perceptions of CRM campaigns and gain a better understanding of the reasons people do or do not respond positively to these promotions with a social dimension. A thorough exploration of consumer perceptions of quality, risk and value with regard to CRM programs is needed to understand how consumers assign meaning to CRM and how these meanings translate into differential responses. This study begins the process of filling this gap in our knowledge. 
The first banking EDI (Electronic Data Interchange) paying system was launched in 1997. This system represented a new generation of Internet banking services. Synthetic electronic banking services began in 1998, and included a new function of allow funds to be transferred between accounts over the Internet. However, information technology may result in reduced transparency during trading and it may increase consumers' perceived risk of banking services. The problem of risk has increased considerably with the advent of on-line service providers. Customers must divulge personal and/or financial information to use these services, yet a website does not provide tangible quality cues, and customers often do not know whether the service provider is "big or small, new or established, legitimate or illegitimate" (Hagel and Singer, 1999). Particularly, increased information asymmetry in e-business leads to perceived risk being included as a possible determinant in the consumption of baking services. So, customer value to consume baking services may decline owing to trading uncertainties.

Banking services were chosen as the object of our study for the following reasons. First, bankers can use convenient trading processes (e.g. e-business) to stimulate consumers' intentions, because of the introduction of information technology, but these new processes may involve more perceived quality, risk and value. Second, owing to ever-increasing competition within banking services, in terms of both costs and banking products, consumer value is playing a vital role in marketing management, since it is widely assumed and assessed to determine overall consumer satisfaction. Hence, this study has three aims. (i) To analyze the major factors or features that affect banking service quality and risk perceived by consumers. (ii) To explore the overall relationship among cause related marketing, service quality, perceived risk and perceived value. (iii) To examine the modulation of the foregoing relationship by the demographic variables.

\section{THEORETICAL BACKGROUND AND HYPOTHESES}

\section{Cause Related Marketing}

In their seminal piece on CRM (Cause Related Marketing), Varadarajan and Menon (1988) provide a comprehensive conceptual examination of CRM and define it as the process of formulating and implementing marketing activities that are characterized by an offer from the firm to contribute a specified amount to a designated cause when customers engage in revenue-providing exchanges that satisfy organizational and individual objectives. Early concerns centered around CRM's 
impact on philanthropy and NPOs (Gurin, 1987). Although these concerns persist (Andreasen, 1996), it is becoming increasingly apparent that the firms involved are more often the target of negative consumer affective and behavioral responses than are the nonprofit recipients (Ellen, Mohr and Webb, 1997). Preliminary research efforts to examine consumer responses to CRM have focused on describing general responses to the concept and measuring how the elements of CRM campaigns affect attitudes and purchase intent. Consumers report being less sensitive to price and product attribute differences after exposure to a CRM campaign (Pracejus and Olsen, 2004). Research indicates that women have more favorable attitudes toward both the firm and the cause than men do (Ross, Patterson and Stutts, 1992).

Several elements of the offer have been found to play a role in consumers' responses, including the type of product being purchased, the importance of the cause to the consumer, and the amount of the donation. Strahilevitz and Myers (1998) find that CRM offers led to a more positive response when promoting luxuries rather than necessities. Lafferty (1996) finds that consumers' responses were more positive when the cause was important to them. However, she also finds that control advertisements (i.e., with no cause mentioned) resulted in more positive attitudes and purchase intentions than a CRM advertisement supporting an unimportant cause. This finding raises important questions for further research. Regarding the size of the donation, Dahl and Lavack (1995) find that consumers were more likely to believe that the corporation was exploiting the NPO when the donation was small (i.e.. 1/4t for each container of juice sold) than when a larger donation (i.e., 100 per package) was made. In contrast, Holmes and Kilbane (1993) find no significant differences in consumer responses to three levels of charitable donations or three price levels. In their study, CRM offers did not have a negative impact on consumer attitudes toward the message, the store, or purchase intentions, even in the presence of disproportionate increases in price relative to the donation being made to the NPO.

In summary, research indicates that, when consumers are asked to evaluate CRM programs in general, they express mostly positive attitudes and purchase intentions.

\section{Service Quality}

Parasuraman, Zeithaml, and Berry $(1985,1988)$ defined perceived service quality as "a global judgment, or attitude, relating to the superiority of the service." They linked the concept of service quality to the concepts of perceptions and expectations in this way: "Perceived quality is viewed as the degree and direction of discrepancy between consumers' perceptions and expectations." Thus, they suggested that 
customers' assessment of overall service quality is based on the gap between their expectations and their perceptions of performance levels. They presented a model of five service quality gaps, and then developed a scale, "SERVQUAL", which was adopted by many researchers. They then reduced the ten dimensions of the original scale to five determinants, including tangible cues, reliability, responsiveness, assurance and empathy. Several researchers (for example, Kwan and Hee, 1994; Athanassopoulos, 1995; Lam, 1995; Hussey, 1999) extended the work to discuss the measuring and evaluating the validity and reliability of service quality. Researches confirmed that SERVQUAL provided validly and reliably measured the quality of the service provided by banks.

Cause related marketing programs could result in favorable consumer attitudes toward the firm, its products (Berger, Cunningham and Kozinets, 1996) and the NPO involved (Ross, Patterson and Stutts, 1992). Since consumers' perceptions of corporate social responsibility can influence their beliefs about and attitudes toward new products or service provided by a company (Brown and Dacin, 1997). Most people believe CRM is a good way to raise money for social causes (Ross, Patterson and Stutts, 1992). Such outcomes are consistent with the notion that CRM can be an important tool for differentiating a brand from its competitors (Murphy, 1997) and, therefore, improving its odds of being purchased. Consumers are likely to perceive a company with a good reputation as being more trustworthy and credible than one with a poor reputation, that should foster lower risk or higher service quality (Bansal and Voyer, 2000; Hendrix, 1999). Moreover, a company takes social responsibility and possess empathy to take care whom should to be noticed. It can raise assurance quality and empathy quality. So we address hypothesis 1 as follow :

Hypothesis 1: Cause related marketing increases service quality

\section{Perceived Risk}

Considering the perceived risk, Engel, Blackwell, and Miniard (1995) defined perceived risk as "those beliefs about the risks associated with product (service) purchase". Cox (1963) first provided five types of risks perceived by the consumers (functional, physical, financial, psychological and social), and Stone (1993) added a sixth type, temporal risk. Stone found that explained $88.8 \%$ of the variance of total perceived risk was explained on these six dimensions. Then, Brooker (1983) extended the work to separate total risk into individual and non-individual risk. Individual risk was related to social risk, and the non-individual risk was related with financial, physical and temporal risks. According to Shimp and Bearden (1982), 
"...higher perceived quality may serve to mitigate the risk that accompanies the uncertainty of whether a product will satisfactorily perform its intended function." Implicit in this statement is that quality mediates the relationship between price and performance risk. This study considers two dimensions of perceived risk: one dimension is related to financial, physical and temporal risk and is termed non-individual risk, and the other dimension is related to social risk and is called individual risk (Brooker, 1983). Additionally, Doweling and Stalin (1994) argue that overall consumer perceptions of risk are governed by numerous factors, including consumer characteristics, the nature of the product under consideration, purchasing context, culture, and so on.

In the present context, consumer perceptions about a company's motivation to support a social cause may influence the degree to which CRM strategies affect consumer choice. These strategies should be more likely to generate choice of the sponsoring brand when consumers infer that the primary motivation for marketers' use of CRM is positive or not risky (e.g., to provide support for the cause) rather than negative or risky (e.g., to exploit the cause as a means of generating sales of the sponsor brand) (Barone, Miyazaki and Taylor, 2000). Accordingly, consumer perceptions of a company's motivation to support social causes have implications for the likelihood that corporate participation in CRM campaigns will positively influence brand choice. Therefore, CRM influence on choice is found to depend on the perceived motivation underlying the company's CRM efforts as well as whether consumers perceive lower risk of this product/service. There is an increasing body of knowledge on the impact of CRM and CSR on marketing performance variables. While Sen and Bhattacharya (2001) report positive effects of CSR initiatives on consumers' perceptions of corporate image. Some academic research findings suggest that consumers are receptive to cause-related marketing and consider corporate participants socially responsible (Brown and Dacin, 1997; Lafferty et al., 2004; Strahilevitz and Myers, 1998). CRM can influence consumer purchase intentions and attitudes (Chaney and Dolli, 2001; Hajjat, 2003) and strengthen corporate credibility perceptions (Yechiam et al., 2003; Lafferty et al., 2004). Thus, CRM can promote corporate image and strengthen the consumers' perceptions of corporate credibility, it can reduce perceived risk. So we address hypothesis 2 as follow :

Hypothesis 2: Cause related marketing decreases perceived risk

Individuals facing high-risk situations tend to seek out information useful in reducing the negative consequences of transactions (Capon and Burke, 1980; 
Schaninger and Sciglimpaglia, 1981). By incorporating elements that convey the five SERVQUAL determinants of assurance, reliability, empathy, responsiveness, and tangibles into their service marketing, banks can increase perceived quality, and thus reduce perceived risk (Clow, 1995). Theoretically, if service quality cues in an advertisement indicate the service will be performed at a high level, the associated risk should be reduced. Restated, if consumers feel a service firm is reliable (for example, possessing adequate and up-to-date equipment), responsive to their particular requests, reassuring, and empathic in caring for them as an individual, then the risk of patronizing that service should be reduced (Clow and Fogliasso 1998). Accordingly, this study asserts the following hypothesis.

Hypothesis 3: Service quality clearly decreases perceived risk

\section{Customer Value}

Customer value has been defined in diverse ways (Zeithaml, 1988). Following Hunt (1995), it is equated here with the worth that customers as individuals, as market segments, or as a mass place on the consequences they attribute to product or service. It stems from perceived or expected performance in satisfying customers' functional and psychic needs (Sheth, Newman and Gross, 1991) and may depend on user networks or on the availability and quality of complements. The concept we are interested in is customer value. The literature suggests that it has two related meanings. Most commonly, customer value means judgments or assessments of what a customer perceives he or she has received from a seller in a specific purchase or use situation (Bagozzi, 1999; Walsh, 1995). Woodruff (1997) draws on several of these value concepts in defining customer value as a "customer's perceived preference for and evaluation of those product attributes, attribute performances, and consequences arising from use that facilitate (or block) achieving the customer's goals and purposes in use situations." Perceptions of customer value can also be viewed as a trade-off between perceived benefits (i.e. perceived product and services quality) and perceived sacrifices (i.e. prices and costs). Empirical research to support these relationships includes studies by Hurley and Laitamaki (1995), Laitamaki and Kordupleski (1997), Higgins (1998) and Rust, Lemon and Zeithaml (2001).

Sheth et al. (1991) identified five consumption values - "functional", "social", "emotional", "epistemic" and "conditional" - which could influence consumer purchase and choice behavior. Levitt (1980) argued that a product represented "a complex cluster of value satisfactions" to buyers, who attached value to the product according to its perceived ability to meet their needs. A brand that satisfies 
customers' practical needs delivers functional value, whereas a brand that satisfies customers' self-expression needs delivers symbolic value (Bhat and Reddy, 1998).

Within the service literature, much effort has been devoted to identifying the antecedents of consumers' intended behavior. However, to date, these efforts have focused primarily on establishing the links between service quality, perceived risk and service value. The result is that we now have a better understanding of the conceptual realm of these variables, as well as how they relate to each other. Specifically, overall service quality is conceptualized as composed of three sub dimensions: employee service performance, physical goods quality, and services cape quality (cf. McAlexander, Kaldenberg and Koenig, 1994; McDougall and Levesque, 1994; Rust and Oliver, 1994). Customer value is identified as functions of consumers' service quality perceptions (Athanassopoulos, 2000; Chenet, Tynan and Money, 1999), and all three are posited to directly affect purchase outcomes (Ennew and Binks, 1999; Sweeney, Soutar and Johnson, 1999). So we address hypothesis 4 as follow :

Hypothesis 4: Service quality clearly increases consumer value

Most literatures generally agree that the benefit side of value includes more than quality and the sacrifice side includes more than price (e.g., Day and Crask, 2000; Holbrook, 1994; Slater and Narver, 2000), even though many practitioners tend to equate value solely with these two dimensions. Recently, a third dimension, risk, has appeared in the literature. Day and Crask (2000) and Huber and Herrmann (2000) propose that risks associated with a product or service should be included in the customer value phenomenon. Dabholkar, Thorpe, and Rentz (1996) report that in their study, respondents regularly listed price as a factor, but the literature clearly suggests that price is a determinant of service value (e.g., Bitner and Hubbert, 1994; Chang and Wildt, 1994; Bolton and Drew, 1991; Heskett, Sasser and Hart, 1990; Zeithaml, 1988). As to each dimension of perceived risk may be expectation of future cost of consumers, which will display the perceived value relative to money (Sweeney, Soutar and Johnson, 1999). In the literature, many researchers have described customers' evaluation of value as a function of monetary and non-monetary costs, such as the sacrifices associated with utilizing the product/service and the benefits or utility received in exchange (Doyle, 1984; Hauser and Urban, 1986). Cause of paying much, consumer would perceive high value. Finally, Sweeney et al (1999) especially explore the causal relationship among service quality, perceived risk and customer value, so we address hypothesis 5 as follow:

Hypothesis 5 : Perceived risks clearly reduce consumer value. 


\section{VARIABLES AND MEASUREMENTS}

First, a research focus and scope were identified, and relevant studies collected for review. Second, an appropriate questionnaire was developed, and discussions were held with managers and experts who are familiar with banking. Reference was made to definitions of and research into variables of cause related marketing, service quality, perceived risk and customer value. Finally, a survey was conducted using the questionnaire, which had been modified in the pretest stage.

Cause related marketing about company motivation was manipulated by varying the information presented about four types (Kotler, 1998). In the large-motivation-difference scenario, Company was portrayed as having positive motivation, and the forth one little motivation to engage in CRM. In the small-difference condition, the first one was depicted as having positive motivation and the forth one neutral motivation; in control conditions, four types were shown as having neutral motivation. They are social issues, which are promoted by company, promoted with NPO (non-profit organization), earning part of the revenue according to this promotion, or only get license from the NPO to earn part of the revenue.

The quality of service in this study is measured on a modified scale based on the SERVQUAL, as represented by Parasuraman et al. (1988), to fit the current banking environment of Taiwan. After extensive interviews with several banking general managers and experts, 40 questions, referring to five dimensions and 29 items from the SERVQUAL, and 11 items related to electronic banking service quality, were selected. The supplementary items to SERVQUAL are, "the steps of the operation of electronic banking are well distinguished", "a breakdown in electronic banking can be recovered in a timely manner", and "personal information is not given out", among others. Finally, 40 items are included in the questionnaire to measure the perception of consumers in Taiwan of the quality of service from a bank.

Perceived risk of banks' service is here categorized into two parts (uncertainty and consequences) and six dimensions (financial, functional, physical, social, psychological and temporal risk). For example, financial risk is evaluated using six questions concerning potential financial crises, interest rates, embezzled accounts, misappropriated credit cards, circulated interest expenses and loss of guarantees. Psychological risk is evaluated using six questions concerning anxiety about disclosed private information, unfinished deals, disappearing banking cards, unreasonable waiting times, pressure to pay, and a potential run on a bank. Physical, functional, social and temporal perceived risks are each measured by three questions. Using a Likert five-point semantic differential scale, subjects are asked to indicate their 
perception of the probability of suffering from a risk and potential consequences thereof. Thus, uncertainty and consequences are identified simultaneously. The multiplication model (Peter and Tarpey, 1975) was employed to determine the probability and consequences associated with each risk.

The values that are emphasized in marketing communications are key since the link between a product or service and a consumer's values is essential for effective positioning. Kamakura and Novak (1992) have noted that an individual value can have multiple interpretations. They propose that segments defined by value systems rather than by a single value will have both more reliability and greater interpretability. Moreover, Sheth et al. (1991) posit that market choice is a function of multiple values, which make differential contributions to the choice situation. Since examining multiple values appears to offer a potentially richer interpretation of behavior, the Sheth et al. (1991) theory of consumption values was used in this study to operationalize the value construct. Five consumption values, based on an amalgam of conceptual frameworks were drawn from economics, psychology, sociology, marketing, and consumer behavior. Sheth et al. (1991) postulated that five consumption values influence consumer choice behavior: (1) functional value (2) social value (3) emotional value (4) epistemic value and (5) conditional value. In this study, we utilize and expand upon these basic consumption values to examine consumers' relationships among variables.

\section{EMPIRICAL RESULTS}

\section{Descriptive Statistics}

This work managed data collection in two stages. In the first stage, authors interview consumers using quota sampling in banks and pre-test scales, to improve the validity of the scales. The coefficient alpha of all dimensions in the pre-tested questionnaire was better than 0.6 , which indicates that they all met reasonable standards of internal consistency and reliability (Nunnally, 1970). In the second stage, 15 interviewers are trained to visit 600 customers of 30 commercial banks in Taipei. This procedure resulted in the loss of fewer than $6 \%$ of all the samples. Finally, 564 valid samples, or $94 \%$ of all samples, were recovered. Non-response bias resulting from the sampling procedure was tested by comparing the survey results with known values for the bank using population relating to the demographic characteristics of sex, age, education, race, and income (Armstrong and Overton, 1977). No significant differences were found $(\mathrm{p}<.05)$, suggesting the sample is reasonably representative of 
the banking consumer population on the demographic variables tested. The typical respondent can be profiled as a female (57.5\%) between 30 and 39 years of age (36.5\%). Most respondents had a college education (34.9\%), were professionals $(31.5 \%)$, and had incomes exceeding $\$ 18,000$ a year $(58.3 \%)$.

\section{Overall Model Evaluation}

Construct validity can be supported by examining the evidence for each construct included appropriate items that loaded at least 0.65 on their respective hypothesized components in a confirmatory factor analysis. We find that loadings on hypothesized factors are significant and substantively large (nearly all factor loadings exceeding 0.65). In addition, the overall goodness of fit supports unidimensionality. The measurement model produced the following fit statistics: comparative fit index (CFI) $=0.95$, normed fit index $(\mathrm{NFI})=0.95$, nonnormed fit index $(\mathrm{NNFI})=0.95$ (exceeding $0.95)$, goodness-of-fit index $(\mathrm{GFI})=0.93$, adjusted goodness-of-fit index (AGFI) $=$ 0.90 (exceeding 0.90 ), root mean square error of approximation $($ RMSEA) $=0.02$, standardized root mean residual $(\mathrm{SRMR})=0.04$ (less than 0.08$)$, chi-square $=100.4$ ( $\mathrm{p}$-value $=0.01)$. This suggests that the hypothesized measurement model of Figure 1 fits data reasonably well.

\section{Measurement Model Evaluation}

We first assessed the quality of our measurement efforts by investigating reliability, convergent validity, discriminant validity, and construct validity. We assess reliability jointly for all items of a construct by computing the composite reliability. For a construct to own good reliability, composite reliability should exceed 0.70 (Bagozzi and Yi, 1988). The internal consistency reliability (Cronbach's alpha coefficient) of the measure of four kinds of cause related marketing were 0.968, 0.796, 0.946, and 0.757, respectively; the five dimensions (tangibles, reliability, responsiveness, assurance and empathy) of service quality measures were $0.749,0.808$, $0.832,0.842$, and 0.846 respectively. Furthermore, the six types (functional, physical, financial, psychological, social and temporal risks) of perceived risks of internal consistency reliability measures were $0.736,0.799,0.887,0.819,0.707$, and 0.837 , respectively; the five kinds (functional, social, emotional, epistemic, and conditional) of customer value were $0.893,0.809,0.897,0.940$, and 0.728 , respectively. All scales demonstrate good reliabilities. 


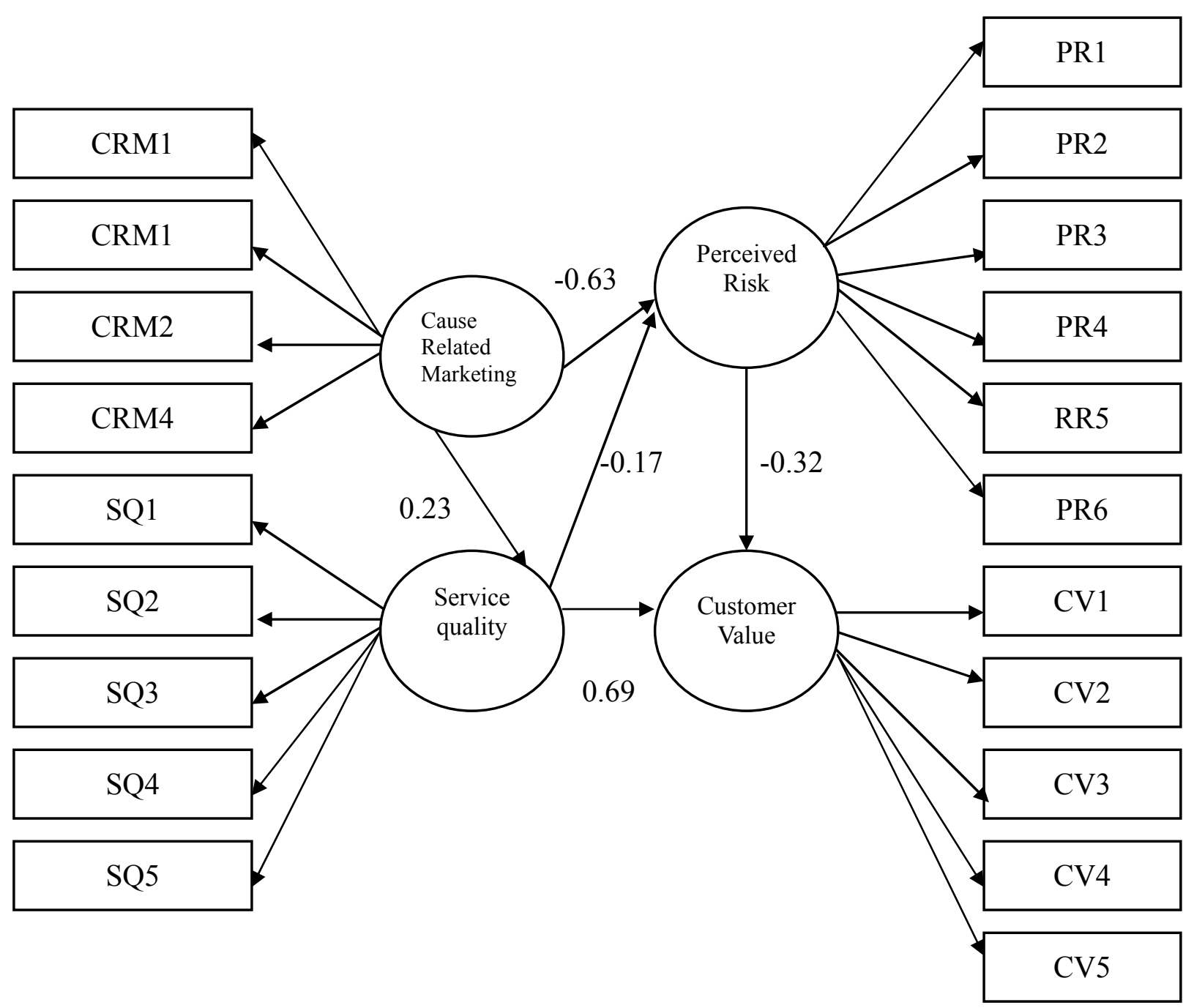

Figure 1 The research framework of the study

As to the assessment on convergent validity, we can support it by conducting a confirmatory factor analysis (CFA) model. It is found that all loadings in Table 1 being significant $(\mathrm{p}<0.05)$ and nearly all R2 exceeding 0.50 (Hildebrandt, 1987). The convergent validity then is hold. 
Table 1 Convergent Validity and Construct Validity: Confirmatory Factor analyses of Service Quality, Perceived Risk and Customer Value

\begin{tabular}{|c|c|c|c|}
\hline Construct Item & Loading & t-value & $\mathbf{R}^{2}$ \\
\hline \multicolumn{4}{|l|}{ Service quality } \\
\hline Tangibles & 0.64 & 14.56 & 0.54 \\
\hline Reliability & 0.88 & 14.07 & 0.59 \\
\hline Responsiveness & 0.63 & 15.68 & 0.63 \\
\hline Assurance & 0.65 & 15.93 & 0.59 \\
\hline Empathy & 0.68 & 17.66 & 0.68 \\
\hline \multicolumn{4}{|l|}{ Perceived risk } \\
\hline Functional & 0.74 & 21.68 & 0.67 \\
\hline Physical & 0.65 & 21.06 & 0.73 \\
\hline Financial & 0.68 & 26.15 & 0.46 \\
\hline Psychological & 0.73 & 19.54 & 0.55 \\
\hline Social & 0.71 & 20.65 & 0.48 \\
\hline Temporal & 0.67 & 21.54 & 0.60 \\
\hline \multicolumn{4}{|l|}{ Customer value } \\
\hline Functional & 0.73 & 22.54 & 0.54 \\
\hline Social & 0.78 & 21.21 & 0.65 \\
\hline Emotional & 0.81 & 23.48 & 0.65 \\
\hline Epistemic & 0.82 & 20.68 & 0.64 \\
\hline Conditional & 0.88 & 26.15 & 0.64 \\
\hline \multicolumn{4}{|l|}{ Goodness-of-fit Statistics } \\
\hline CFI & 0.96 & ---- & \\
\hline NFI and NNFI & 0.96 & 0.96 & \\
\hline GFI and AGFI & 0.92 & 0.89 & \\
\hline RMSEA and SRMR & 0.02 & 0.01 & \\
\hline Chi-square (d.f.) & 564 & 45 & \\
\hline
\end{tabular}

Note: Based on one-tailed tests: for t-values greater than $1.65\left(^{*}\right), \mathrm{p}<0.05$; for-t-values Greater than $2.33, \mathrm{p}<0.01(* *)$. 
Table 2a Convergent Validity and Discriminant Validity Analysis: Inter-Corrections of Service Quality and Perceived Risk

\begin{tabular}{cccccccccccc}
\hline Item & SQ1 & SQ2 & SQ3 & SQ4 & SQ5 & PR1 & PR2 & PR3 & PR4 & PR5 & PR6 \\
\hline SQ1 & $\mathbf{1 / 0 . 7 4}$ & & & & & & & & & & \\
SQ2 & $0.348^{*}$ & $\mathbf{1 / 0 . 8 0}$ & & & & & & & & \\
SQ3 & $0.341^{*}$ & $0.519^{*}$ & $\mathbf{1 / 0 . 8 4}$ & & & & & & & & \\
SQ4 & $0.452^{*}$ & $0.389^{*}$ & $0.484^{*}$ & $\mathbf{1 / 0 . 8 3}$ & & & & & & & \\
SQ5 & $0.466^{*}$ & $0.437^{*}$ & $0.376^{*}$ & $0.399^{*}$ & $\mathbf{1 / 0 . 8 5}$ & & & & & & \\
PR1 & -0.019 & -0.052 & -0.018 & -0.007 & -0.038 & $\mathbf{1 / 0 . 7 3}$ & & & & \\
PR2 & -0.018 & -0.050 & -0.076 & -0.036 & -0.040 & $0.404^{*}$ & $\mathbf{1 / 0 . 7 9}$ & & & \\
PR3 & -0.022 & -0.063 & -0.185 & -0.107 & -0.120 & 0.374 & $0.427^{*}$ & $\mathbf{1 / 0 . 8 8}$ & & & \\
PR4 & -0.006 & -0.015 & -0.073 & -0.029 & -0.088 & 0.427 & $0.543^{*}$ & $0.413^{*}$ & $\mathbf{1 / 0 . 8 1}$ & & \\
PR5 & -0.004 & -0.059 & -0.045 & -0.105 & -0.107 & $0.304^{*}$ & $0.317^{*}$ & $0.298^{*}$ & $0.326^{*}$ & $\mathbf{1 / 0 . 7 0}$ & \\
PR6 & -0.002 & -0.010 & -0.010 & -0.071 & -0.011 & $0.362^{*}$ & $0.502^{*}$ & $0.356^{*}$ & $0.327^{*}$ & $0.428^{*}$ & $\mathbf{1 / 0 . 8 3}$ \\
\hline
\end{tabular}

Note: about the name of abbreviation (e.g., SQ1, SQ2, etc), please refer as figure 1.

All values are significant at $\mathrm{p}=0.05$.

Table 2b Convergent Validity and Discriminant Validity Analysis: Inter-Corrections of Service Quality and Customer Value

\begin{tabular}{ccccccccccc}
\hline Item & SQ1 & SQ2 & SQ3 & SQ4 & SQ5 & CV1 & CV2 & CV3 & CV4 & CV5 \\
\hline SQ1 & $\mathbf{1 / 0 . 7 4}$ & & & & & & & & & \\
SQ2 & $0.348^{*}$ & $\mathbf{1 / 0 . 8 0}$ & & & & & & & & \\
SQ3 & $0.341^{*}$ & $0.519^{*}$ & $\mathbf{1 / 0 . 8 4}$ & & & & & & & \\
SQ4 & $0.452^{*}$ & $0.389^{*}$ & $0.484^{*}$ & $\mathbf{1 / 0 . 8 3}$ & & & & & & \\
SQ5 & $0.466^{*}$ & $0.437^{*}$ & $0.376^{*}$ & $0.399^{*}$ & $\mathbf{1 / 0 . 8 5}$ & & & & & \\
CV1 & 0.074 & 0.034 & 0.011 & 0.043 & 0.049 & $\mathbf{1 / 0 . 8 9}$ & & & & \\
CV2 & 0.040 & 0.008 & 0.023 & 0.008 & 0.038 & $0.421^{*}$ & $\mathbf{1 / 0 . 8 0}$ & & & \\
CV3 & 0.023 & 0.010 & 0.006 & 0.013 & 0.036 & $0.373^{*}$ & $0.423^{*}$ & $\mathbf{1 / 0 . 8 9}$ & & \\
CV4 & 0.046 & 0.023 & 0.013 & 0.087 & 0.122 & $0.307^{*}$ & $0.411^{*}$ & $0.383^{*}$ & $\mathbf{1 / 0 . 9 4}$ & \\
CV5 & 0.009 & 0.014 & 0.035 & 0.108 & 0.018 & $0.425^{*}$ & $0.371^{*}$ & $0.472^{*}$ & 0.332 & $\mathbf{1 / 0 . 7 2}$ \\
\hline
\end{tabular}

Note: about the name of abbreviation (e.g., SQ1, SQ2, etc), please refer as figure 1.

All values are significant at $\mathrm{p}=0.05$. 
As to the discriminant validity, we first checked whether correlations among the latent constructs were significant less than one (see Table 2). We then compared a series of nested confirmatory models in which correlation coefficient between similar attributes/constructs, should exceed that of between different attributes/constructs. The intercorrelation among the service quality and perceived risk ranges from 0.30 to 0.52 ; among the service quality and customer value ranges from 0.31 to 0.52 , and constraining this correlation to unity invariably produced a significant change in the goodness-of-fit statistic.

Table 3 The Empirical Results of Structural Models

\begin{tabular}{lccc}
\hline \multicolumn{1}{c}{ Hypothesized Path } & Estimated Coefficient & T value & p-value \\
\hline H1: CRM $\rightarrow$ Service Quality & $\beta_{1}=0.23$ & 11.45 & 0.043 \\
H2: CRM $\rightarrow$ Perceived Risk & $\beta_{2}=-0.63$ & -11.64 & 0.045 \\
H3: Service Quality $\rightarrow$ Perceived Risk & $\beta_{3}=-0.17$ & -9.56 & 0.015 \\
H4: Service Quality $\rightarrow$ Customer Value & $\beta_{4}=0.69$ & 16.21 & 0.015 \\
H5: Perceived Risk $\rightarrow$ Customer Value & $\beta_{5}=-0.32$ & -13.23 & 0.016 \\
\hline Goodness-of-fit Statistics (df.) & $(153)$ & & \\
Chi-square (p-value) & 100.40 & 0.00 & \\
GFI and AGFI & 0.93 & 0.88 & \\
NFI and NNFI & 0.95 & 0.96 & \\
CFI & 0.95 & -- & \\
RMSEA and SRMR & 0.022 & 0.022 & \\
\hline
\end{tabular}

Note: Based on one-tailed tests: for t-values greater than $1.65\left(^{*}\right), \mathrm{p}<0.05$; for-t-values Greater than $2.33, \mathrm{p}<0.01(* *)$.

\section{Structural Model Evaluation}

Table 3 indicates that each sample, all significant relationships between latent constructs are in the hypothesized direction, which provides initial evidence for our conceptual model and supports the mono-logical validity of the constructs. Cause related marketing was the dominant antecedent of perceived risk (H2: $\beta 2=-0.63)$. Service quality and perceived risk, the commonly accepted consequences, both had a significant effect on customer value. Amongst, the former has a larger effect $(\mathrm{H} 4$ : $\beta 4=0.69)$, and the latter a small effect $(\mathrm{H} 5: \beta 5=-0.32)$. In addition, cause related marketing was found to influence service quality $(\mathrm{H} 1: \beta 1=0.23)$ positively. This, 
service quality had a small but significant negative influence on perceived risk $(\mathrm{H} 3$ : $\beta 3=-0.17)$.

In order to fully understand the relative importance of the constructs in developing loyalty, the total effects of each constructs/variables on endogenous variables such as cause related marketing; service quality, perceived risk, and customer value were examined. These are shown in table 4. In each cell, the direct effect (as in table 3), the indirect effect and the total effect (direct plus indirect) of one construct on another is shown. For example, cause related marketing had a significant influence on perceived risk (-0.67), having a small indirect effect (-0.04) but a substantially larger direct effect (-0.63). Similarly, service quality had a small indirect effect on customer value (0.05), but a much larger direct effect (0.69). Thus, the important role played by the banking service provider in creating customer value took place largely through their cause related marketing.

Table 4 Direct, Indirect, and Total Effect on Endogenous Variables/Constructs

\begin{tabular}{lccc}
\hline \multicolumn{1}{c}{ Path } & Direct Effect & Indirect Effect & Total Effect \\
\hline 1. CRM $\rightarrow$ Service Quality & 0.23 & & 0.23 \\
2. CRM $\rightarrow$ Perceived Risk & -0.63 & -0.04 & -0.67 \\
3. Service Quality $\rightarrow$ Perceived Risk & -0.17 & & -0.17 \\
4. Service Quality $\rightarrow$ Customer Value & 0.69 & 0.05 & 0.74 \\
5. Perceived Risk $\rightarrow$ Customer Value & -0.32 & & -0.32 \\
\hline
\end{tabular}

Note: For example, the total effect of CRM $\rightarrow$ Perceived Risk $(-0.67)$ comprised the direct effect $\left(\beta_{2}=-0.63\right)$ plus the indirect effect through service quality $\left(\beta_{1} * \beta_{3}=0.23 *-0.17=-0.04\right)$.

\section{A Rival Model}

It is generally agreed that researchers should compare rival models and not just test the performance of proposed model (Bagozzi and Yi, 1988). Given that our primary hypothesized model allows no direct paths from cause related marketing to customer value. An alternative rival model would hypothesize direct paths from cause related marketing to customer value. This alternate model makes cause related marketing similar to perceived quality permits no indirect effects on customer value, implying that service quality and perceived risk are not allowed to mediate any of the cause related marketing and customer value (see figure 2). 


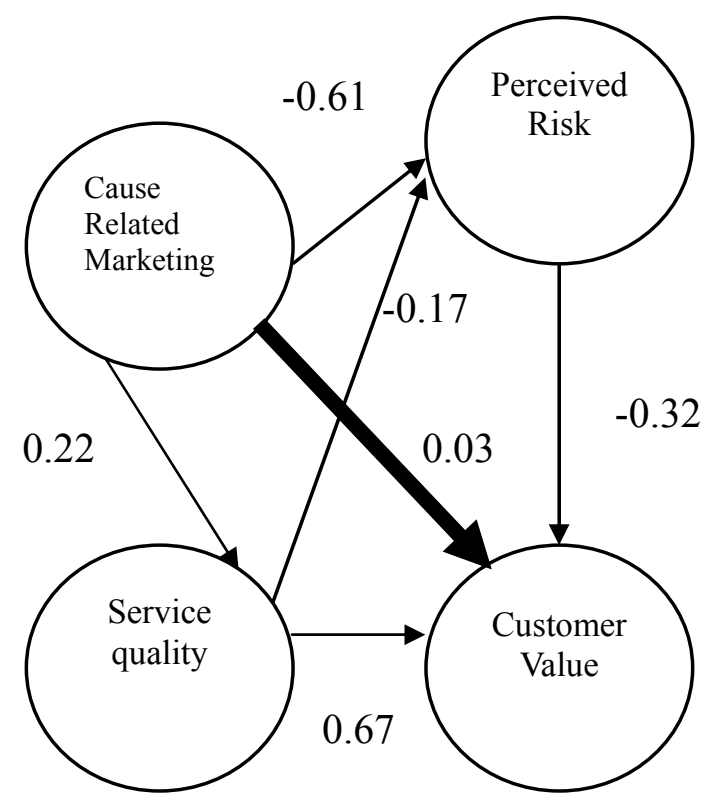

Figure 2 The rival model of the study

We compared our hypothesized model with the rival model based on the overall fit, parsimony, and percentage of either model's parameters that were statically significant, and R2 for the endogenous constructs. First, the CFI of the rival model was nearly indifferent with the hypothesized model ( 0.93 versus 0.95$)$. Second, only $63 \%$ of the paths in the rival model were significant as opposed to $88 \%$ in the hypothesized model, which implied that the additional paths were not meaningful theoretically or empirically. Third, the R 2 of customer value was only 0.72 in the rival model as opposed to 0.81 in the hypothesized model. In contrast, the R2 of cause related marketing was 0.25 in the rival model as opposed to 0.26 in the hypothesized model. This suggested that the explanatory power of cause related marketing, as direct factor of customer value is not stronger than the combined explanatory power of service quality and perceived risk together in indirect way. Thus, we then support that our hypothesized model is meaningful and robust.

\section{CONCLUSIONS REMARKS}

The purpose of this research is to propose a casual relationship linkage among the cause related marketing, service quality, perceived risk, and customer value of banking service. We aim to examine the casual relationship between cause related marketing and customer value. One of the contributions of this study is to highlight 
the factors influencing customer value from a perspective of two variables of service quality and perceived risk. With banking services towards enhancing its competitiveness and becoming increasingly involved in cause related marketing, an investigation into the casual relationship between cause related marketing and customer value through service quality and perceived risk, which may improve the value perceived by consumers.

This study highlights the strategy of cause related marketing, which will directly decrease the perceived risk in response to the needs of positive business image. We have further investigated the relationship between service quality and perceived risk. Our results reveal that cause related marketing of banking service provider could increase the value perceived by customer and mostly through the decrease of perceived risk. An effort into the current marketing niche of cause related marketing such as to grant authorization from non-profitable organization could decrease the perceived risk and increase the value of customers.

This study investigates the issue of assessing customer value to produce insight into two meaningful factors (service quality and perceived risk) for diagnosing the cause related marketing strategy. Cause related marketing, which can influence customers' beliefs about and attitudes toward new products or service provided by a company (Brown and Dacin, 1997), result in favorable consumer attitudes toward the firm, its products (Berger, Cunningham, and Kozinets 1996). Recent marketing actions have tended to be focused on the positive image of firm or brand, rather than the value of consumers, and which is influenced by service quality and perceived risk. Assessing this customer value model is important because the relationships imply the influencing path perceived by consumers. The extent of value from conducting the cause related marketing actions is normally higher than of from proceeding traditional marketing activities.

Also note that a number of notable findings are reported including the empirical verification that cause related marketing could influence customer value mainly by the decrease of perceived risk, rather than service quality. According to the data in table 4 , there are three ways for cause related marketing to affect customer value, which are by the variable of service quality $(0.159=0.23 * 0.69)$, by the variable of perceived risk $(0.202=-0.63 *-0.32)$, and the third way by the both variables $(0.013=0.23 *-0.17 *$ -0.32). Thus, cause related marketing mainly influenced customer value by the way of perceived risk. The reason may be that cause related marketing influence on choice is found to depend on the perceived motivation underlying the company's cause related marketing efforts as well as whether consumers perceive lower risk of this service. 
As to each dimension of perceived risk may be expectation of future cost of consumers, which will display the perceived customer value (Sweeney, Soutar and Johnson, 1999). Hence, lower risk can result in lower future cost, which displays higher customer value.

Finally, researchers wish to provide ways of market segments to enable marketing managers to confirm marketing opportunities, meet customers' demands, and develop corresponding marketing strategies with niches for each target market. For example, in Taiwan, cause related marketing adopted by many banks clearly enhances the social image or fame of banks, and indirectly boosts their funds and performance. Considering the empathy of service quality perceived by consumers with reduced psychological risk might be the critical reason to increase their consuming value and intension. Further, consumers have various characteristics (desires, cognition, purchasing power and attitudes) that can serve as a basis for segmenting markets. A suitable communicating or marketing mix, and the use of various cues of service quality, are advantageous.

\section{ACKNOWLEDGEMENT}

The authors would like to thank the National Science Council of the Republic of China for financially supporting this research under Contract No. NSC 91-2416-H-130-002.

\section{REFERENCES}

Andreasen, A. R. (1996). Profits for nonprofits: find a corporate partner. Harvard Business Review, 74(6), 47-59.

Armstrong, J. S. and T. S. Overton (1977). Estimating nonresponse bias in mail survey. Journal of Marketing Research, 14(3), 396-402.

Athanassopoulos, A. D. (1995). Service quality and operating efficiency synergies for management control in the provision of financial services: evidence from Greek bank branches. European Journal of Operational Research, 98(2), 300-313.

Athanassopoulos, A. D. (2000). Customer satisfaction cues to support market segmentation and explain switching behavior. Journal of Business Research, 47, 191-207.

Bagozzi, R. P. and Y. Yi (1988). On the evaluation of structure equations models. Academic of Marketing Science, 16(1), 76-94.

Bagozzi, R. P. (1999). Goal setting and goal striving in consumer behavior. Journal of Marketing, 63, 19-32. 
Bansal, H. S. and P. A. Voyer (2000). Word-of-mouth processes within a service purchase decision context. Journal of Service Research, 3, 166-177.

Barnes, N. G. and D. A. Fitzgibbons (1992). Strategic marketing for charitable organizations. Health Marketing Quarterly, 9(3), 103-114.

Barone, M. J., A. D. Miyazaki, K. A. Taylor (2000). The influence of cause-related marketing on consumer choice: does one good turn deserve another?. Journal of the Academy of Marketing Science, 28(2), 242-262.

Berger, I. E., P. H. Cunningham and R. V. Kozinets (1996). The processing of cause-related marketing claims: cues, biases, or motivators? in 1996 AMA Summer Educators Conference: Enhancing Knowledge Development in Marketing, Vol. 7, 71-72.

Bhat, S. and, S. K. Reddy (1998). Symbolic and functional positioning of brands. Journal of Consumer Marketing, 15(1), 32-43.

Bitner M. J. and A. R. Hubbert (1994). Encounter satisfaction versus overall satisfaction versus quality: the customer's voice in Service Quality: New Directions in Theory and Practice. California: SAGE Publications.

Bolton, R. N. and J. H. Drew (1991). A multistage model of consumers' assessments of service quality and value. Journal of Consumer Research, 17, 375-384.

Brooker, G. (1983). An assessment of expanded measure of perceived risk. Advances In Consumer Research, 10, 439-441.

Brown, T. J. and P. A. Dacin (1997). The company and the product: corporate associations and consumer product responses. Journal of Marketing, 61(Jan), 68-84.

Capon, N. and M. Burke (1980). Individual, product class, and task-related factors in consumer information processing. Journal of Consumer Research, 7, 314-326.

Chaney, I. and N. Dolli (2001). Cause-related marketing in New Zealand. International Journal of Nonprofit and Voluntary Sector Marketing, 6(2), 145-63.

Chang, T. Z. and A. J. R. Wildt (1994). Price, product information and purchase intention : an empirical study. Journal of the Academy of Marketing Science, 22(1), 16-27.

Chenet, P., C. Tynan, and A. Money (1999). Service performance gap: re-evaluation and redevelopment. Journal of Business Research, 46, 133-147.

Clow, K. E. (1995). Advertising health care services. Journal of Health Care Marketing, 15(2), 9-11. 
Clow, K. E. and C. Fogliasso (1998). Reducing perceived risk through advertising service quality cues. Journal of Professional Services Marketing, 16(2), 151-162.

Cox, D. F. (1963). The audience as communicators. in Toward Scientific Marketing, Proceedings of the Winter Conference of the American Marketing Association, Stephen A. Greyser, ed. Chicago: American Marketing Association.

Dabholkar, P. A., D. I. Thorpe and J. O. Rentz (1996). A measure of service quality for retail stores: scale development and validation. Journal of the Academy of Marketing Science, 24(1), 3-16.

Dahl, D. W. and A. M. Lavack (1995). Cause-related marketing: impact of size of cause-related promotion on consumer perceptions and participation. in 1995 AMA Winter Educators Conference: Marketing Theory and Applications, Vol. 6, 476-481.

Day, E. and M. R. Crask (2000). Value assessment: the antecedent of customer satisfaction. Journal of Consumer Satisfaction, Dissatisfaction and Complaining Behavior, 13, 52-60.

Doweling, R. and R. Stalin (1994). A model of perceived risk and intended risk-handling activity. Journal of Consumer Research, 21(6), 110-134.

Doyle, M. (1984). New ways of measuring value. Progressive Grocer-Value, Executive Report, 15-19.

Drumwright, M. E. (1996). Company advertising with a social dimension: the role of noneconomic criteria. Journal of Marketing, 60(Oct), 71-87.

Ellen, P. S., L. A. Mohr and D. J. Webb (2000). Charitable Programs and the Retailer: Do they Mix? Journal of Retailing, 76(3), 393-406.

Engel, J.F., Blackwell, R.D. and Miniard, P.W. (1995). Consumer Behavior, 8th ed.. The Fort Worth, TX: Dryden Press.

Ennew, C. T. and M. R. Binks (1999). Impact of participative service relationships on quality, satisfaction and retention: an exploratory study. Journal of Business Research, 46, 121-132.

Gurin, M. G. (1987). Cause-related marketing in question. Advertising Age, 27(1), 5-16.

Hagel III, J. and M. Singer (1999). Unbundling the corporation. Harvard Business Review, 77(5), 133-141.

Hajjat, M. M. (2003). Effect of cause-related marketing on attitudes and purchase intentions: the moderating role of cause involvement and donations size. Journal of Nonprofit and Public Sector Marketing, 11(1), 93-109. 
Hauser, J. R. and G. Urban (1986). The value priority hypotheses for consumer budget plans. Journal of Consumer Research, 12( Mar), 446-462.

Hendrix, P. E. (1999). Build it, and they will come. Marketing Management, 8, 31-35.

Heskett, J. L., W. E. Sasser and C. W. L. Hart (1990). Service breakthroughs: Changing the rules of the game. New York: The Free Press.

Higgins, K. T. (1998). The value of customer value analysis. Marketing Research, 10(4), 38-44.

Hildebrandt, L. (1987). Consumer retail satisfaction in rural areas: A reanalysis of survey data. Journal of Economic Psychology, 8(11), 19-42.

Holbrook, M. B. (1994). The nature of consumer value. In Roland T. Rust and Richard L. Oliver (Eds.), Service Quality: New Directions in Theory and Practice (pp. 21-71). CA: Stage Publications.

Holmes, J. H. and C. J. Kilbane (1993). Selected effects of price and charitable donations. Journal of Nonprofit \& Public Sector Marketing, 1(4), 67-83.

Huber, F. and A. Herrmann (2000). The role of customer value in arriving at an assessment of satisfaction: results of a causal analytic study. In Harlan E. Spotts and H. Lee Meadow (Eds.), Developments It Marketing Science (pp. 110-115). FL: Academy of Marketing Science.

Hunt, S. D. (1995). The comparative advantage theory of competition. Journal of Marketing, 59(Apr), 1-15.

Hurley, R. F. and J. Laitamaki (1995). Total Quality Research: Integrating Markets and the Organization. California Management Review, 38(1), 59-78.

Hussey M. K. (1999). Using the concept of loss: An alternative SERVQUAL measure. The Service Industries Journal, 19(4), 89-101.

Kamakura,W. A. and T. P. Novak (1992). Value-system segmentation: exploring the meaning of LOV. Journal of Consumer Research, 19(Jun),119-132.

Kotler, P. (1998). Marketing Management: Analysis, Planning, Implementation and Control (9th ed.). NJ: Prentic-Hall Inc.

Kwan, W. and T. J. Hee (1994). Measuring service quality in Singapore retail banking: a gap analysis and segmentation approach. Singapore Management Review, 16, $1-24$.

Lafferty, B. A., \& R. E. Goldsmith (2005). Cause-brand alliances: does the cause help the brand or does the brand help the cause? Journal of Business Research, 58(1), 423-429. 
Lafferty, B. A., R. E. Goldsmith, and G. T. M. Huit (2004). The impact of the alliance on the partners: a look at cause-brand alliances. Psychology \& Marketing, 21(7), 509-531.

Laitamaki, J. and R. Kordupleski (1997). Building and deploying profitable growth strategies based on the waterfall of customer value added. European Management Journal, 15(2), 156-66.

Lam, S. S. (1995). Assessing the validity of SERVQUAL: an empirical analysis in Hong Kong. Asia Pacific Journal of Quality Management, 4, 33-41.

Levitt, T. (1980). Marketing success through differentiation - of anything. Harvard Business Review, 58(2), 83-91.

Macleod, S. (2001). Why worry about CSR?. Strategic Communication Management, $5(5), 8-9$.

Maignan, I. and D.A. Ralston (2002). Corporate social responsibility in Europe and the US: insights from businesses self-presentations. Journal of International Business Studies, 33(3), 497-514.

McAlexander, J. H., D. Kaldenberg and H. F. Koenig (1994). Service quality measurement. Journal of Health Care Marketing, 3 (Fall), 34-40.

McDougall, G. H. G. and T. J. Levesque (1994). A revised view of service quality dimensions: an empirical investigation. Journal of Professional Services Marketing, 11(1), 189-209.

Mohr, B. A., D. J. Webb and K. E. Harris (2001). Do consumers expect companies to be socially responsible? the impact of corporate social responsibility on buying behavior. The Journal of Consumer Affairs, 35(1), 45-72.

Murphy, I. P (1997). Pillsbury proves charity, marketing begins at home. Marketing News, February 17, 16.

Nunnally, J. C. (1970). Introduction to Psychological Measurement.New York : McGraw-Hill.

Parasuraman, A., V. A. Zeithamal, and L. L. Berry (1985). Conceptual model of service quality and its implications for future research. Journal of Marketing, 49, 47-35.

Parasuraman, A., V. A. Zeithamal, and L. L. Berry (1988). SERVQUAL: a multiple-item scale for measuring consumer perceptions of service quality. Journal of Retailing, 64(1), 12-40.

Peter, J. P. and L. X. Tarpey (1975). A comparative analysis of three consumer decision strategies. Journal of Consumer Research, 2, 29-37.

Pracejus, J. W. and G. D. Olsen (2004). The role of cause/ brand fit in the effectiveness 
of cause-related marketing campaigns. Journal of Business Research, 57(6), 635-640.

Ross, J. K., L. Patterson and M. A. Stutts (1992). Consumer perceptions of organizations that use cause-related marketing. Journal of the Academy of Marketing Science, 20(1), 93-97.

Rust, R. T. and R. L. Oliver (1994). Service quality: insights and managerial implications from the frontier. In Roland T. Rust and Richard L. Oliver (Eds.), Service Quality: New Directions in Theory and Practice (pp. 1-19). CA: Sage.

Rust, R. T., K. N. Lemon and V.A. Zeithaml (2001). Driving customer equity: linking customer lifetime value to strategic marketing decisions. Marketing Science, 26, $1-54$.

Sen, S. and C. B. Bhattacharya (2001). Does doing good always lead to doing better? consumer reactions to corporate social responsibility. Journal of Marketing Research, 38(2), 225-243.

Schaninger, C. M., and D. Sciglimpaglia (1981). The influence of cognitive personality traits and demographics on consumer information acquisition. Journal of Consumer research, 8 (Sep), 208-216.

Sheth, J. N., B. Newman and B. L. Gross (1991). Consumption Values and Market Choices. Cincinnati: OR South-Western Publishing Co.

Shimp, T. A. and W. O. Bearden (1982). Warranty and other extrinsic cue effects on consumers' risk perception. Journal of Consumer Research, 9 (June), 38-46.

Slater, S. F. and J. C. Narver (2000). Intelligence generation and superior customer value. Journal of the Academy of Marketing Science, 28(Winter), 120-127.

Stone, R. N. and K. Gronhaug (1993). Perceived risk: further considerations for the marketing discipline. European Journal of Marketing, 27(3), 39-50.

Strahilevitz, M. and J. G. Myers (1998). Donations to charity as purchase incentives: how well they work may depend on what you are trying to sell. Journal of Consumer Research, 24(4), 434-446.

Sweeney, J. C., G. N. Soutar and L. W. Johnson (1999). The role of perceived risk in the quality-value relationship: a study in a retail environment. Journal of Retailing, 75(1), 77-105.

Varadarajan, P. R. and A. Menon (1988). Cause-related marketing: a coalignment of marketing strategy and corporate philanthropy. Journal of Marketing, 52(July), 58-74. 
Walsh, J. W. (1995). Flexibility for consumer purchasing for uncertain future tastes. Marketing Science, 14(2), 148-165.

Woodruff, R. B. (1997). Customer value: the next source for competitive advantage. Journal of the Academy of Marketing Science, 25(2), 139-53.

Yechaim E., G. Barron, I. Erev and M. Erez (2003). On the robustness and the direction of the effect of cause-related marketing. Journal of Consumer Behavior, 2(4), 320-332.

Zeithaml, V. (1988). Consumer perceptions of price, quality, and value: a means-end model and synthesis of evidence. Journal of Marketing, 52(July), 2-22. 
